\title{
TEKNOLOGI PEMBELAJARAN PAI
}

\author{
Hamdan Suyuti ${ }^{1}$, Sas Fitriyana ${ }^{2}$, Yushinta Eka Farida, M.Pd ${ }^{3}$ \\ 1,2,3 Universitas Islam Nahdlatul Ulama Jepara \\ hamdantrans85@gmail.com, sasfitriyana83@gmail.com, faridayushinta@gmail.com
}

\begin{abstract}
The teaching of Islamic Religious Education in school institutions often fails, even though the students have been given these lessons, but they often do not use them and do not apply what they have learned through their schools, PAl learning in schools seems to be a distraction and no more important than in other lessons. Adapting to the technological era, learning activities are required to reduce the use of the lecture method but with the method of using learning media, the media in this learning is very important. Information and communication technology is a program of tools to convey information to students. The learning process of Islamic religious education can be easier in finding information, managing and transferring knowledge or transferring information, so that Information and Communication Technology in the learning process plays an important role in developing the learning process, and improving teacher professionalism in teaching by using Information and Communication Technology, especially in PAl field. Broadly speaking, teachers can apply such as by means of graphic media, audio media, silent projection media, game media and simulations. With the media, it can turn schools into creative and dynamic learning institutions so that they can motivate students to always want to know in PAl learning.
\end{abstract}

Keywords: Information and Communication Technology, Learning Technology, Learning Media

\begin{abstract}
Abstrak: Pengajaran Pendidikan Agama Islam di lembaga sekolah sering menuai kegagalan, meskipun siswa tersebut sudah di beri pelajaran tersebut, namun mereka seringkali tidak menggunakanya dan tidak mengaplikasikan apa yang telah diperoleh mereka melalui sekolahanya, pembelajaran PAI di sekolah seolah-olah menjadi pelajaran selingan dan tidak lebih penting darai pada pelajaran yang lainya. Beradaptasi dengan era teknlogi, kegiatan pembelajaran dituntut mengurangi dengan penggunaan metode ceramah teteapi dengan metode penggunaan media pembelajaran, media dalam pembelajaran ini sangat penting. Teknologi informasi dan komunikasi merupakan suatu program alat bantu untuk dalam menyampaikan informasi kepada siswa. Proses Pembelajaran Pendidikan Agama Islam dapat lebih mudah dalam mencari informasi, pengelolaan dan transfer ilmu atau pemindahan informasi, sehingga Teknologi Informasi dan Komunikasi dalam proses pembelajaran menjadi peran penting dalam mengembangkan proses belajar, dan meningkatkan profesional guru dalam mengajar dengan menggunakan Teknologi Informasi dan Komunikasi khususnya dalam bidang PAI. Secara garis besar guru dapat mengaplikasikan seperti dengan cara media grafik, media audio, media proyeksi diam, media permainan dan simulasi. Dengan adanyaa media tersebut dapat mengubah sekolah menjadi instusi pembelajaran yang kreatif dan dinamis sehingga dapat memotivasi siswa selalu ingin tahu dalam pembelajaran PAI.
\end{abstract}

Kata Kunci: Teknologi Informasi dan Komunikasi, Teknologi Pembelajaran, Media Pembelajaran

\section{PENDAHULUAN}

Proses belajar mengajar merupakan aktivitas antara guru dengan siswa didalam kelas. Dalam pembelaran terdapat proses untuk menyiapkan materi yang akan di sampaikan diantaranya media,guru,siswa,dalam proses belajar mengajar adalah dengan keaktifan siswanya dengan gurunya dengan menyiapkan rangkaian materi yang akan disampaikan ole guru ke siswanya. Dalam proses belajar mengajar,strategi sangatlah dibutuhkan sekali untuk tercapaikan kegiatan belajar 
mengajar yg efektif dan berkualitas sehingga siswa bisa menerima materi yang di sampaikan oleh gurunya dan bisa mempraktekkan dalam kehidupan sehari-hari.

Untuk mencapai tujuan pembelajaran ditetapkan, ada 4 strategi belajar mengajar. Strategi itu adalah (1) mengidentifikasikan materi yang di sampaikan ole gurunya (2)siswa bisa mempraktekkan ilmunya di lingkungannya sesuai harapan masyarakat,(3) memilih dan menetapkan metode dan teknik belajar mengajar yang di anggap paling tepat dan aktif sehingga dapat dijadikan pegangan guru dalam melaksanakan pembelajaran (4) menetapkan norma dan batas minimal keberhasialan atau kritetia standart keberhasilan sehingga dapat dijadikan pedoman guru dalam mengevaluasi kegiatan belajar mengajar atau kepentingan kegiatan pembelajaran.

Pendidikan Agama Islam memiliki peran penentu dalam membentuk karakteristik manusia sebagaimana yang diuraikan diatas, PAl tidak hanya membahas tentang ibadah namun ada juga masalah muamalah, oleh karena itu tanggung jawab guru agama/guru PAI sangatlah berat sekali tidaklah mudah, guru PAI harus mempersiapkan materi yang akan disampaikan kepada anak didiknya sehingga bisa terampil secara vertikal maupun horizontal( zayadi 2005) Langkah strategis yang tepat pada masa akhir akhir ini yaitu dengan memanfaatkan teknologi yang ada di sekeliling kita,karna alat bantu teknologi sangatlah membantu sekali untuk memudahkan proses belajar mengajar.

Pemikiran tersebut berdasarkan paradigma konstruktif ciri khas dari paradigma ini yaitu active learning student/pendekatan cara belajar siswa aktif (Asri, 1985:25). Metode pembelajaran meletakkan siswa dikelas yang dominant, sebab paradigma konstruktivistik itu peranan siswa dalam proses belajar yang landasanya kokoh dalam terbentuknya manusia dimasa depan yang diharapkan.

Untuk memperjelas teknologi konstruktiviktis penulis memaparkan apa yang dimaksud dengan teknologi yang ada bagaimana belajar dalam paradigma konstruktivistik, dan bagaimana pembelajaran Agama Islam dalam paradigma kontruktivistik.

\section{METODE}

Dalam melakukan penelitian ini peneliti menggunakan metode kualitatif. Pendekatan kualitatif pada dasarnya dilaksanakan agar menemukan data yang akurat dan penuh makna (Afifuddin \& Saebani, 2012, p. 59). Teknik pengumpulan data mengandalkan telaah dokumen. Telaah dokumen mempunyai beberapa pengertian. Pertama, 
dokumen mencakup seluruh sumber, baik secara lisan dan secara tulisan. Kedua mencakup seluruh sumber tulisan saja. Ketiga, dokumen mencakup surat-surat resmi dan negara. Seperti halnya surat-surat perjanjian, undang-undang, konsesi, dan lain-lain (Gunawan, 2014, pp. 175- 176).Metode pengambilannya, peneliti menggunakan buku-buku, jurnal, artikel, dokumen, dan lain sebagainya. Dokumen yang digunakan sudah tepat pada judul yakni Teknologi pembelajaran PAI.

\section{HASIL}

Dalam membahas teknologi pembelajaran PAI memang belum jelas, namun konsep yang mendasari munculnya pembahasan tentang teknologi pembelajaran semenjak proses pembelajaran itu sendiri, hal ini dapat dilihat diera sofisme, dalam proses belajar mengajar di masa ini kaum sofi sudah menggunakan system tutor, kemudian di masa sokratos mengenai metode maeutik/metode inkjuiri ada beberapa kemajuan waktu masa karel agung oleh tokohnya abelard dan sic et non nya (sujana, 2003 : 3), hal ini terus ada kemajuan sampai pada awal abad ke 20, semakin berkembangnya ilmu pengetahuan tentang pembelajaran, maka semakin berkembang pembentukan konsep teknologi pendidikan pembelajaran sebagai sebuah disisplin ilmu yang integral. Konsep teknologi pendidikan dan teknologi pembelajaran untuk orang tertentu sangat membingungkan bahkan beberapa orang kurang benar memaknainya, dalam hal ini dijelaskan oleh AECT (association for educational and teknology), education tecnology is often confused with instructional tecnology and teknology in education (percifal, 1984 : 34).Teknologi pembelajaran dapat diartikan sebagai suatu yang menghubungkan dengan teknologi dan media yang digunakan dalam pembelajaran seperti overhead projector, Televisi, rekaman video,Google Book, Erlening, Google Meet, Zoom Metting, Whats App dan aplikasi lainnya, teknologi pembelajaran merupakan suatu kegiatan proses belajar mengajar yang sistematis sebagai usaha untuk mencapai keefektifan belajar mengajar yang optimal.

Asosiasi komunikasi dan teknologi pendidikan (Assosiation for Educational Communications and Tecnology / AECT) memiliki definisi teknologi pendidikan yaitu suatu proses yang berkelompok yang melibatkan id, peralatan, prosedur dan juga manusia adapun kegiatan organisasi dalam menganalisis aspek belajar manusia, selanjutnya teknologi pembelajaran mempunyai bagian dari teknologi pendidikan. Sutijadi mendefinisikan teknologi pembelajaran adalah proses yang berkelompok dan terpadu yang melibatkan manusia, prosedur, id, peralatan, dan organisasi dalam 
memecahkan suatu masalah, melaksanakan, mengevalkuasi kemudian memproses pemecahan masalah dalam situasi kegiatan belajar mengajar yang memiliki tujuan yang terkontrol (Sutijadi, 1992 : 3). Dari beberapa definisi tersebut diartikan pemikiran teknologi pembelajaran pada dasarnya berkaitan dengan bagaimana menciptakan proses belajar mengajar yang efektif dan efisien. Hal ini dalam pemikiran teknologi pendidikan yang berparadigma konstrukfistik. Paradigma beranggapan bahwa apabila dalam belajar mengajar dilaksanakan kepada murid yang aktif maka akan memperoleh hasil dari proses pembelajaran yang berarti (meaningfull learning), maka dari itu murid akan mendapatkan hasil dari proses belajarnya.

\section{PEMBAHASAN}

Untuk pembelajaran PAI (Pendidikan Agama Islam) dalam bidang sudy mempunyai dua karakteristik yaitu bidang study yang bermuatan pengetahuan (transfer of knowldge) dan juga bidang study yang bermuata nilai (transfer of value).

Dalam hal ini mengandung pengertian bahawa Pendidikan Agama Islam merupakan mata pelajaran yang tidak hanya memeberikan modal pengetahuan tetapi juga memebrikan modal moral kepada siswa. Dengan itu guru PAI mempunyai tanggung jawab yang tidak ringan terhadap ketercapaian dari tujuan pemelajaran tersebut, karena memberikn materi dikelas tidaklah cukup untuk menyampaikan informasi, tapi harus bisa menanamkan nilai moral terhadap siswa, oleh karena itu supaya pembelajaran PAI mempunyai arti yang harus dilandasi pada sebuah perangkat system yang lebih baik lagi. Perangkat tersebut harus dmulai dari perencanaan yang benar-benar matang, dengan pemaparan strategi yang baik, dan juga alat evaluasi yang relevan.

Dan tanggung jawab seorang guru PAI tidakalah ringan, pemikiran konstruktivistik memebrikan alternative jawaban untuk guru supaya pada pembelajaran PAI mempunyai dampak yang positive bagi setiap individu, karena pada pembelajaran yang berbasis konstruktivistik mempunyai karakteristik bahwa sebuah pembelajaran harus menekankan pada keaktifan siswa (active learning) dalam hal tersebut menemukan hasil dari sebuah pembelajaran pada dasarnya hal itu diasumsikan bahwa proses rangsangan belajar dilakukan dengan rangsangan gerak maka akan menambahkan sedikit ketingkatan terhadap siswa dalam mencapai tujuan pemebelajarannya. 
Apabila proses rangsangan belajarnya hanya dengan suara (cermah) maka kemungkinan hanya sedikit saja perolehan yang di terima oleh siswa dalam memperoleh tujuan pembelajarannya, dan hal yang sama mungkin lebih sedikit lagi yang diperoleh dari rangsangan rasa. Rangsangan gerak ) pada paradigma konstruktivistik menjadikan landasan untuk pembelajaran PAI yang menekankan pada kebermaknaan pengetahuan, sebab apabila sebuah pengetahuan tidak bermakana maka proses pembelajaran PAI tidak akan ada manfaatnya bagi siswa, fenomena ini seringkali terjadi pada masyarakat misalnya masyarakat tahu perbuatan korupsi tidak boleh, tetapi mereka tetap banyak yang melakukannya, sholat tepat waktu adalah yang terbaik tetapi masih banyak yang melakukan sholat di undur atau di akhir waktu bahkan banyak juga yang meninggalkan shlolatnya.

Padahal mereka tahu bahwa hukum sholat lima waktu adalah wajib, demikian juga fenomena tersebut sering dijumpai dilembaga pesantren, para santri yang telah mengetahui ghasab (memakai barang yang bukan miliknya tanpa seizin yang punya, tetapi ada niat untuk mengembalikannya) adalah sesuatu yang dilarang tapi mereka tetap melakukannya. Dari contoh-contoh diatas merupakan fenomena konkrit bahwa pembelajaran PAI kurang bermakna, karena mereka hanya tahu pada tingkatan pemahaman saja dan mereka juga kurang mampu mengaplikasikan.

Kebermaknaan (maningfull) dalam proses pemebelajaran PAI sangat penting untuk dicapai karena di harapkan produk dalam pembelajara PAI akan menghasilkan siswa yang mempunyai motivasi intrisic. Dalam melaksanakan ibadah dan muamalhnya dengan motivasi insric siswa juga bisa melaksanakan dengan adanya unsur kepaksaan, namun dengan menuruti hati nuraninya sendiri. Dalam pembelajaran PAI tersebut aktivitas banyak bertanya perlu di ingatkan, diprekdisikan pada saat ini dalam pembelajaran masih banyak siswa yang belum seacara aktif bertabya dalam proses pembelajaran PAI.

Apabila hal itu benar, maka penyebab adanya kurangnya siswa untuk memberanikan diri supaya lebih aktif untuk bertanya dikarenaka ada beberapa beberapa faktor. Faktor pertama yaitu siswa sudah merasa cirinya tidak lebih tau dari guru, sebagai akibat dari keiasaan belajar yang satu arah, kedua adanya ganjalan psikologis karena guru tersebut lebih dewasa daripada usia siswa, dan ketiga kurang kratifnya seorang guru untuk memancing atau mengajukan persoalanpersoalan yang menetang siswa untuk bertanya. 
Oleh karena itu, ada tugas guru PAl yang perlu dilakukan supaya siswa aktif dan yang perlu dilakukan guru tersebut yaitu mencairkan hambatan psikologis atara guru dengan siswa, guru memperkarya sebuah topic pembelajaran yang aktual dengan perekmbangan zaman dengan kontekstual untuk kebutuhan siswa tersebut.

\section{SIMPULAN}

Teknologi pembelajaran merupakan sebuah upaya pemikiran bagaimana menciptakan proses belajar-mengajar yang efektif dan efisien agar proses dan hasil pembelajaran dapat bermakna (meaning full learning) sehingga pembelajran dapat memiliki kompetensi dalam kehidupanya.

Belajar dalam pandangan kostrutifis TIK merupakan proses menemukan pengetahuan yang diadaptasikan oleh struktur kognitif dan pengalaman belajar dengan lingkungan sekitarnya, sehingga interaksi yang dibangun dalam kelas kostruktifistik adalah interaksi aktif dilakukan oleh siswa, bukan gurunya.

Pembelajaran pendidikan Agama Islam paradigm kostruktifistik adalah agar pembelajaran PAI bermakna maka harus dilakukan dengan cara siswa aktif, karena dengan keaktivan siswa dalam mengkonstruksi pengetahuannya tentang PAI yang diharapkan mempunyai dampak terbentuknya motivasi yang intrinsic dalam melaksanakan amalan ibadah dan muamalahnya sebagai produk belajar agama islam.

\section{DAFTAR PUSTAKA}

[1] Zayadi, Ahmad. 2005. Tadzkirah : Pembelajaran Pendidikan Agama Islam berdasarkan kontekstual. Jakarta : Raja Grafindo Persada.

[2] Warsito dkk. 2002. Panduan Sosialisasi Kurikulum Berbasis Kompetensi. Surabaya : Dinas Jatim.

[3] Setijadi. 1992. Definisi Teknology Pendidikan. Jakarta : Rajawali.

[4] Departemen Pendidikan dan Kebudayaan. 1995. Kamus Besar Bahasa Indonesia. Jakarta : Balai Pustaka 